Accepted refereed manuscript of:

Phillips G, Willby N \& Moss B (2016) Submerged macrophyte decline in shallow lakes: What have we learnt in the last forty years?, Aquatic Botany, 135, pp. 37-45.

DOI: 10.1016/i.aquabot.2016.04.004

(C) 2016, Elsevier. Licensed under the Creative Commons AttributionNonCommercial-NoDerivatives 4.0 International 
Botany

\section{Elsevier Editorial System(tm) for Aquatic}

\section{Manuscript Draft}

Manuscript Number: AQBOT3032R1

Title: Submerged macrophyte decline in shallow lakes; what have we learnt in the last forty years?

Article Type: SI: 40 years Aquatic Botany

Section/Category: SI: 40 years Aquatic Botany

Keywords: shallow lakes; nutrients; alternative states; change; acrophyte ecology

Corresponding Author: Prof. Geoff Phillips,

Corresponding Author's Institution: University of Stirling

First Author: Geoff Phillips

Order of Authors: Geoff Phillips; Nigel Willby; Brian Moss 


\title{
Submerged macrophyte decline in shallow lakes; what have we learnt in the last forty years?
}

\author{
${ }^{*}$ Geoff Phillips ${ }^{1}$, Nigel Willby ${ }^{1}$, and Brian Moss ${ }^{2}$ \\ ${ }^{1}$ School of Biological and Environmental Sciences, University of Stirling, Stirling, FK9 4LA, UK \\ ${ }^{2}$ School of Environmental Sciences, University of Liverpool, Liverpool, L69 3GS, UK \\ *Corresponding author (Geoff.phillips@stir.ac.uk)
}

\section{1. Abstract}

2 Over the last 40 years there has been substantial evidence that high biomasses of submerged aquatic

3 plants and phytoplankton rarely occur together in shallow lakes, but it is clear that when present, plants

4 have a competitive advantage over algae.

5 Aquatic plants provide habitat structure, which influences the fish community such that zooplankton

6 and other macroinvertebrates maintain a top-down control on algal growth, and this control is largely

7 independent of the nutrient supply to the lake. Nonetheless it is clear that many, but not all, lakes lose

8 their vegetation as nutrient loading increases. However, in eutrophic lakes, the subsequent dominance

9 by phytoplankton is more likely to be a result of the loss of vegetation rather than the cause.

10 At higher nutrient levels, grazing or mechanical damage can reduce plant cover allowing rapid

11 development of algae. Changes to fish community structure or the influence of toxic chemicals can

12 reduce invertebrate algal grazers, overcoming the positive feedback loops that stabilise the plant

13 dominance.

14 The longer-term stability of macrophyte dominance is also reduced if there are few surviving plant

15 species. Such loss of species richness is associated with increased nitrogen loading. Submerged plants

16 also depend on a spring clear-water phase to become established, and local weather conditions during 
17 winter and spring may determine the relative success of phytoplankton and plant growth, leading to a

18 progressively longer period of algal dominance and fewer surviving plant species.

19 The loss of submerged vegetation from lakes, although often perceived as a rapid change, is more likely

20 to be the final conclusion of a process in which the competitive advantage of a diverse plant community

21 is eroded by many pressures that are collectively interpreted as eutrophication.

22 In attempts to manage our environment we hope to find simple, closed stable systems that will respond

23 to measures designed to meet our perceptions of improved ecological quality. What we increasingly

24 find are more complex open systems, which do not necessarily respond as expected. We look for simple

25 and widely applicable explanations where none are likely to exist.

26 Key words: shallow lakes, nutrients, alternative states, change, macrophyte ecology

\section{2. Introduction}

28 Forty years ago, ecological studies of shallow lakes intensified in response to the growing problems

29 arising from eutrophication. A particular concern at that time, at least in the UK, was the obvious loss of

30 submerged aquatic vegetation, its replacement by phytoplankton and the resulting loss of invertebrate

31 diversity (Morgan, 1970; Mason and Bryant, 1975; Phillips et al., 1978). Macrophyte loss is now clearly

32 recognised as being intimately linked with eutrophication, particularly in shallow lakes where the photic

33 zone extends over the majority of the bed, (Hargeby et al., 1994; Blindow et al., 2006) and many

34 attempts have been made to reverse this process (Moss, 1983; Moss et al., 1996a; Hilt et al., 2006;

35 Søndergaard et al., 2007). The success of lake restoration is often judged by how rapidly macrophytes

36 return, yet we still struggle to elucidate the ecological mechanisms for either the initial decline of

37 macrophytes or their frequently slow response to nutrient reduction (Lauridsen et al., 2003;

38 Søndergaard et al., 2007; Bakker et al., 2012). 
It was early recognised that in very shallow lakes it might not be easy to account for macrophyte loss

40 simply through increased competition for light as a result of phytoplankton growth, and a model was

41 therefore proposed where increased periphyton growth initially suppressed plant growth, with

42 phytoplankton subsequently becoming dominant (Phillips et al., 1978). This hypothesis pre-dated the

43 idea of alternative equilibria that has become so important in understanding shallow lake systems

44 (Uhlmann, 1980; Irvine et al., 1989; Scheffer et al., 1993), but it was a perhaps an augury of the concept, as it assigned macrophytes to a central stabilising role in the functioning of shallow lakes. What has emerged over the last forty years is a clearer understanding of how macrophytes influence the ecology

47 of shallow lakes, in particular the positive feedback systems that maintain what are now widely recognised as the alternative stable states of macrophyte-dominated clear water and planktondominated turbid water (Jeppesen et al., 1998b; Burks et al., 2006).

When present, extensive macrophyte beds sequester nutrients (Blindow, 1992b; Ozimek et al., 1993;

51 Van-Donk et al., 1993; Kufel and Kufel, 2002), provide refuges from visual predators on grazing

52 zooplankton (Timms and Moss, 1984; Schriver et al., 1995), and may produce allelopathic exudates (Van

53 Donk and Van de Bund, 2002; Gross et al., 2007), all of which mitigate against phytoplankton growth

54 and thus maintain clear water conditions (Figure 1). Conversely, when macrophytes are absent, small

55 planktivorous fish reduce zooplankton grazing, and, free of the influence of visual predators in the

56 increasingly turbid water, can reach high densities thus promoting phytoplankton dominance (Jeppesen

57 et al., 1997). Numerous studies have demonstrated that these alternative states can exist over a

58 relatively wide range of nutrient conditions (Leah et al., 1980; Balls et al., 1989; Irvine et al., 1989;

59 Jeppesen et al., 2000; Jeppesen et al., 2003). Clear water and macrophyte-dominance conventionally

60 define the initial state of unimpacted shallow lakes, though whether this is truly a 'reference' state, or

61 merely one that reflects the shifting baseline effect of drift in perception, is a moot point. There are

62 indications that prior to expansion of human populations and depletion of large, nutrient-redistributing 
grazing herds, some shallow lakes may naturally have been rich in nutrients and have had characteristics that we would now see as detrimental (Moss, 2015). It is clear, nonetheless, that most become plankton dominated under the pressure of nutrient addition, whether natural or artificial, while current aims of conservation philosophy, which are perhaps more focused on issues of biodiversity than ecological processes, are to maintain clear water with low-moderate nutrient concentrations in which a high diversity and cover of macrophytes can thrive. In this review, we summarise what we have learnt over the last 40 years about the mechanisms that overcome the apparent stability of this system to allow phytoplankton to become dominant, and how this should influence our approach to restoration.

\section{3. Light availability and competition with algae}

72 While at a very broad geographic scale, the proportion of lakes dominated by submerged macrophytes

73 clearly decreases with increases in total phosphorus (TP) and total nitrogen (TN), logistic models

74 quantifying this relationship show wide variation, which can be linked, through climatic differences, to

75 the relative production of algal biomass and water depth, suggesting that light may still be a key issue

76 (Kosten et al., 2009). Early reports of macrophyte loss following eutrophication assumed this was a

77 consequence of reduced light availability caused by phytoplankton development (Mason and Bryant,

78 1975), as it had already been established by correlation that in deep lakes light was a key factor

79 influencing the depth distribution of macrophytes (Spence and Chrystal, 1970). This nutrientchlorophyll-light relationship remains true (Chambers and Kalff, 1985; Sand-Jensen and Madsen, 1991;

81 Middelboe and Markager, 1997), although the relationship between the maximum colonised depth of

82 macrophytes and nutrient concentrations is weak, not least because of the influence of coloured

83 dissolved organic substances and suspended inorganic matter, whose concentrations are largely

84 independent of nutrients. This suggests a more complex relationship linking nutrients to the distribution

85 and development of macrophytes (Søndergaard et al., 2013) and one which does not necessarily assume that the loss of macrophytes is consequential on nutrient increase and phytoplankton development. 
87 In 1978, Phillips et al. pointed out that in very shallow lakes, phytoplankton growth may not reduce light

88 sufficiently to prevent the growth of submerged macrophytes and suggested that shading by epiphytic algae was the primary factor causing macrophyte decline. Since then, the capacity for epiphytic algal growth to reduce light availability has been confirmed (Sand-Jensen and Borum, 1991) and thus to reduce macrophyte growth (Sand-Jensen and Søndergaard, 1981; Daldorph and Thomas, 1995; Jones et al., 1999; Roberts et al., 2003). The impact of epiphytes (or periphyton, as a common term for all attached living and dead material), is particularly important in shallow water, where the relative effect of light attenuation by phytoplankton is lower. For example, the epiphyte community that developed on

95 Lobelia dortmanna attenuated the incident light in spring by between 67 and $82 \%$, substantially reducing growth and maximum depth of colonisation from 3.5 to $1.0 \mathrm{~m}$ (Sand-Jensen and Borum, 1984).

97 The relationship between nutrients and periphyton in lakes is, however, variable. Some studies demonstrate an increase of periphyton with nutrients (Moss, 1976; Eminson and Phillips, 1978; Cattaneo and Kalff, 1980; Eminson and Moss, 1980; Jones et al., 1999; Jones et al., 2000; Bécares et al., 2007; Beresford and Jones, 2010) and a greater response than phytoplankton (Sand-Jensen and Søndergaard, 1981). However, others only found an impact of nutrients when fish were present 102 (Mazumder et al., 1989) or no relationship (Lalonde and Downing, 1991; Lambert et al., 2008). Using 103 experimental ponds, Jones et al. (2002) found that periphyton abundance on the surface of plants was 104 controlled by the density of grazing invertebrates rather than nutrient load, confirming previous experimental studies which have demonstrated the beneficial impact of snails on submerged macrophyte growth via the removal of epiphytes (Brönmark, 1985; Underwood, 1991; Underwood et 107 al., 1992).

109 Kornijow, 1998), though probably not to the same extent that they influence populations of 110 zooplankters in the much less structured open water environment (e.g. compare Moss et al. (1998) and 
111 Kornijów et al. (2016)). Experimental manipulation of fish has demonstrated that in enclosures devoid of

112 molluscivorous (e.g. Lepomis microlophus) or benthivorous (e.g. Tinca tinca) fish, invertebrate grazers

113 increased, reducing periphyton and increasing macrophyte biomass (Martin et al., 1992; Brönmark,

114 1994). Direct manipulation of invertebrate (snail) densities produces similar results (Underwood, 1991;

115 Underwood et al., 1992). Elger et al. (2009) also demonstrated that selective predation of seedling

116 macrophytes by snails could alter the final community developing from the propagule bank, thus

117 highlighting a mechanism by which grazers could influence not just the abundance of plants but also

118 their composition. Thus there is clear evidence that a top-down effect of fish on macrophyte growth can

119 occur via a fish-macroinvertebrate-periphyton-macrophyte pathway, as first proposed by Brönmark and

120 Weisner (1992). This mechanism complements the well-established planktonic trophic cascade via the

121 fish-zooplankton-plankton-macrophyte pathway (Jeppesen et al., 1997). Thus we now know that both

122 periphyton and phytoplankton provide a mechanism limiting light for macrophytes and that both can be

123 influenced by top-down controls in addition to nutrients (Figure 1).

\section{4. Relevance to alternative states hypothesis}

125 Light availability is clearly also important for periphytic algal growth, and as a result the relationship 126 between nutrients and periphyton can be complicated by the shading influence of phytoplankton

127 (Hansson, 1988; Bécares et al., 2007). In a survey of 13 Danish lakes, Liboriussen and Jeppesen (2006)

128 found that periphyton biomass on artificial substrata was unimodally related to TP, with a peak biomass

129 at intermediate concentrations $\left(60-200 \mu \mathrm{g} \mathrm{TP}^{-1}\right)$, being progressively nutrient limited at lower and

130 light limited at higher concentrations. These values are within the range of nutrients often associated

131 with a transition between alternative stable states in shallow lakes and suggests that high epiphytic algal

132 growth is most probable at intermediate nutrient concentrations unless controlled by grazers,

133 particularly snails, which are more efficient than other invertebrate grazers (Underwood et al., 1992).

134 Liboriussen et al. (2005), using mesocosms in clear and turbid water lakes, showed that both fish and 
light availability affected the biomass of periphyton, with the strongest top-down control in clear water

136 lakes. Thus the stabilising influence of invertebrate grazing on macrophytes, via a benthic feedback loop,

137 may be potentially more important during eutrophication than during nutrient reduction. In addition,

138 density of plant-associated invertebrates is inevitably lower in lakes where macrophytes have been

139 absent for several years (Hargeby et al., 1994) and thus it may take some time for recolonisation of

140 appropriate invertebrate grazers to re-establish this mechanism, adding to the potential for instability in

141 lakes subject to nutrient reduction. Prolific growth of benthic algae has been observed in clear water

142 lakes following biomanipulation of the fish community (Stansfield et al., 1999); this might be due to the

143 absence of the normal invertebrate grazing control but a rapid population increase of invertebrate

144 grazers unchecked by fish predation could also produce a similar outcome owing to selective grazing on

145 young regenerating plants (Elger et al., 2009). In a survey of 17 plant-dominated shallow lakes in UK,

146 Jones and Sayer (2003) found supporting evidence for the importance of this mechanism, as submerged

147 plant biomass was shown to be unrelated to nutrient concentration or water transparency, but was

148 significantly related to periphyton biomass, which in turn was significantly related to number of grazing

149 invertebrates and fish density. Thus we now have experimental and survey evidence for a more

150 complex model of eutrophication in shallow lakes, whereby increasing nutrient levels increase the

151 potential for both epiphytic and planktonic algal growth, but the expression of this is controlled by

152 invertebrate grazers, which in turn are influenced by fish predation (Figure 1).

153 Quasi-stable states are maintained by a variety of buffer mechanisms (Moss et al., 1996a) and the

154 interaction of fish, grazing invertebrates and properties of the plants themselves reflect these. There is

155 still controversy as to whether nutrients alone can drive a switch from macrophytes to algal dominance.

156 This is usually assumed and a body of hysteresis theory has been built around this assumption, but there

157 is no definitive evidence for it. Where plants have declined at high nutrient levels, there have always

158 been confounding variables, such as ingress of trace organic substances from sewage effluents that 
might have toxic effects on grazing invertebrates, particularly Daphnia. Where, in experimental systems,

160 such possibilities have been removed, addition of large amounts of nutrients has been associated with

161 increased plant growth, albeit sometimes with a redistribution of biomass from submerged to floating

162 species (McKee et al., 2002; Feuchtmayr et al., 2009). The hypothesis of alternative states originally

163 rested (Irvine et al., 1989) on the states being alternatives over broadly the same environmental

164 conditions, including nutrient status. There has been some drift in meaning of the term as research in

165 this area has become popular and this complicates the interpretations different investigators have

166 placed on their results. However, the concept of buffer mechanisms needing to be overcome by a switch

167 mechanism (Moss et al., 1996b) for states to change is still extant (Moss, 2007).

\section{5. The switch mechanisms}

169 Given that alternative clear and turbid states are possible, it seems probable that some external

170 pressure must occur to cause a switch between the two equilibria (Bender et al., 1984). In many cases,

171 the loss of plants is reported as a rapid change (Moss, 1983; Bales et al., 1993; Hargeby et al., 2007;

172 Tátrai et al., 2008; Randsalu-Wendrup et al., 2014) and to explain this we seek major events. There are

173 plenty of direct and indirect mechanisms that destroy plants at a local scale through mechanical,

174 chemical and grazing damage (Moss et al., 1996a), thus destroying directly the stabilising aquatic plant

175 community. However, others interfere with the stabilising feedback mechanisms, such as catastrophic

176 changes to fish populations. This could be a fish kill caused either by winter ice cover, where for example

177 the loss of piscivores results in an increase of planktivorous fish (Hall and Ehlinger, 1989; Isermann et al.,

178 2004), or summer depletion of oxygen removing planktivorous and benthivorous fish (Carvalho, 1994;

179 Jeppesen et al., 1998a). Such events do occur and undoubtedly can influence the survival of

180 macrophytes, but it is unlikely that they are sufficiently common to single-handedly account for the

181 widespread reported loss of macrophytes. 
A more insidious and potentially general mechanism than fish kills would be the effect of pollutants

183 other than nutrients acting directly on the grazers. Examples have been suggested to explain the loss of

184 plants from the shallow lakes that constitute the Broads, a system of medieval man-made lakes and

185 wetlands in eastern England. Here palaeolimnological studies have demonstrated an association

186 between macrophyte loss and elevated levels of tributyltin (TBT), an organotin compound used since the

187 1960s as a biocide in antifouling paints which were widely applied to boats in these inland waters (Sayer

188 et al., 2006), and the pesticides DDT and dieldrin (Stansfield et al., 1989). These authors suggest that in

189 an environment of increased nutrient loading, which existed at the time, macrophyte decline may have

190 been precipitated by the loss of grazing invertebrates, both molluscs and zooplankton, caused by these

191 chemicals. Waste water treatment effluent is often the source of nutrients whose increase may

192 heighten the risk of a switch from plants to algae occurring, but it is rarely acknowledged that effluents

193 are much more complex chemically than simple nutrient solutions. They contain a very large range of

194 heavy metals, trace organics, and salts, including endocrine disruptors, other pharmaceuticals and vanity

195 products (Mills and Chichester, 2005) most of which have not been tested in circumstances where they

196 may cause subtle effects on growth of zooplankton and other invertebrates. This is a largely unexplored

197 area that merits further attention.

198 There is also a strong relationship between wildfowl biomass and macrophyte abundance (Wood et al.,

199 2012), with herbivorous wildfowl showing a positive relation to periods of clear water and high

200 macrophyte density (Hansson et al., 2010). Bird grazing has been reported to remove significant

201 proportions of annual macrophyte production (Mitchell, 1989; Lodge, 1991; Woollhead, 1994) and bird

202 grazing could be another destabilising influence on macrophyte dominance, having the added impact of

203 releasing nutrients into the water column. On the assumption that plant palatability and nutritional

204 quality will increase with productivity as plants invest proportionally more in growth than defence, and

205 tissue nutrient contents increase, per capita consumption by herbivores ought to increase with 
productivity. Whether this translates to increased impacts of herbivores at higher productivity remains

207 unclear, although there is evidence to support this (Gayet et al., 2011; Bakker and Nolet, 2014).

208 However, the impact of birds has only been clearly shown using small exclosures in lakes where

209 macrophytes are recolonizing, or in experimental ponds (Lauridsen et al., 1993; Søndergaard et al.,

210 1996; Hilt, 2006). Coot (Fulica atra) and mute swan (Cygnus olor) are prolific macrophyte grazers but

211 using estimates of grazing rates, and abundance of macrophyte beds in Lake Krankesjön, Sweden

212 Hansson et al., (2010) showed that only $2.6 \%$ of macrophyte biomass was removed and similar

213 conclusions were reached for Botshol, a small shallow lake in Netherlands dominated by charophytes

214 (Rip et al., 2006). Moreover, grazing is likely to be most intense in the autumn when bird numbers reach

215 peaks but macrophytes are already senescing, though whether this opens up the possibility of impacts in

216 subsequent years is unclear. However, in urban lakes and bird reserves, where wildfowl densities may

217 be artificially high owing to supplementary feeding, there are usually no macrophytes and dense algal

218 growths or muddy water (B Moss personal observations). As with fish populations, effects of birds are

219 therefore likely to be density-dependent. The possibility that there are other higher trophic level

220 interactions with macrophytes mediated by diving duck such as tufted duck (Aythya fuligula), pochard

221 (Aythya ferina) or omnivorous species such as coot, has rarely been considered, although there is some

222 evidence that these species increase in numbers following fish removal and vegetation recovery and,

223 presumably, an increase in invertebrate prey density.

224 In some cases, grazing by semi-aquatic rodents, such as coypu (Myocaster coypus) or muskrat (Ondatra

225 zibethicus), may also be important. In the Broads, coypu escaped from fur farms and became endemic

226 from the 1950s until they were eradicated in the late 1980s. It had been assumed that their diet was

227 largely marginal emergent vegetation and they were therefore likely to have been primarily responsible

228 for loss of marginal reed swamp (Boorman \& Fuller 1981), but there is significant evidence from the

229 southern US and Italy where coypu are also invasive that their diet can be dominated by submerged 
231 Calthorpe Broad confirm the level of reliance on aquatic vegetation of invasive coypu in the UK (Gosling,

232 1974). Even low densities of a native aquatic rodent, the beaver, have been found to exert a significant

233 impact on deeper water swamp species such as Schoenoplectus lacustris in Scotland (Willby et al., 2014).

234 Such species are key architects of littoral zone complexity and their loss from the Broads, regardless of

235 cause, is likely to have precipitated the decline of a diverse aquatic flora of sheltered margins (Madgwick

236 et al., 2011). Given that the carrying capacity of beavers in Norfolk has been estimated at 18-40

237 territories (<200 animals) (South et al., 2001), while numbers of coypu in Norfolk may have been as high 238 as 20,000 in the mid 1970 s (Gosling, 1974) it seems highly likely that coypu exerted an unsustainable

239 level of grazing pressure on littoral marginal vegetation and associated macrophytes. At their natural

240 carrying-capacity the effects of beavers on aquatic vegetation are likely to be sustainable, since animals

241 abandon territories after 5 years or so, moving to other sites, during which vegetation recovery in

242 former territories is likely. Elsewhere, large populations of grazing mammals and their predators also co-

243 exist with rich and abundant macrophyte populations, for example the capybara, jacaré and jaguar in

244 the Pantanal. There are dangers in attributing fundamental importance to the behaviour of introduced

245 species like coypu, without their predators, in situations that are far from natural, though with changing

246 climate and ongoing invasions such situations may increasingly become the norm.

247 Benthivorous fish can also influence macrophyte survival, through physical uprooting (Zambrano and

248 Hinojosa, 1999) and disturbance of sediment (Ibelings et al., 2007). In a survey of 28 lakes, Zambrano et

249 al. (2006) found that lakes with high benthivorous fish biomass were characterized by few macrophyte

250 species and it is the introduction of such fish that may precipitate macrophyte loss (Zambrano et al.,

251 2001). Plants were apparently lost as a result of fish stocking from a lake at Llandrindod Wells in mid-

252 Wales, which received extremely low-nutrient inflows. Common carp (Cyprinus carpio) were shown to

253 mobilize nutrients from the sediments in summer and large algal crops ensued (Moss et al., 2002). 
254 Similarly, vigorous mechanical clearance (Balls et al, 1989) or excessive motorboat activity (Willby \&

255 Eaton, 1996) and even the damage wrought by extreme storms, may act as switch mechanisms,

256 although the evidence tends to be anecdotal.

257 All of the above factors are possible mechanisms which could act as destabilizing influences. While they

258 are most often considered in isolation, the likely norm is that they operate in combinations that differ

259 between lakes, and will vary individually in their severity in response to climatic factors. Some are likely

260 to increase in importance with nutrient concentrations whilst others could potentially affect any lake,

261 though their impacts may be greater at higher nutrient concentrations.

\section{6. Rapid switches or gradual transitions?}

263 While the switch from clear to turbid water sometimes occurs relatively suddenly, historical records and

264 palaeolimnology on a decadal - centennial timescale show that there is often a more gradual shift, with

265 reducing macrophyte abundance and diversity rather than sudden loss (Sand-Jensen et al., 2000;

266 Davidson et al., 2005; Sayer et al., 2010a). Initially, there is a decline in small, slow-growing, rosette-

267 leaved species and charophytes (Blindow, 1992a; Sand-Jensen et al., 2000), and their replacement by a

268 more prolific growth of taller canopy-forming plants, such as Ceratophyllum and Potamogeton species,

269 in response to reduced light availability (Blindow, 1992a; Brodersen et al., 2001). This was demonstrated

270 experimentally in ponds in the USA (Moss, 1976) where charophytes predominated at low and medium

271 nutrient concentrations and Elodea at high concentrations but with reduced total biomass, attributed to

272 phytoplankton shading. In sheltered environments, the increase in water-column nutrients may also see

273 an increase in cover of free-floating macrophytes. So, while remaining macrophyte-dominated, water

274 clarity may reduce and with it the number or density of macrophyte species. For example, Sayer et al.

275 (2010a) demonstrated a reduction over time from 10 or more taxa to 4 in a small shallow alkaline lake,

276 resulting in a less structurally complex system. Analyses of large scale spatial (Willby et al., 2012) or long 
277 term (Phillips et al., 2015) datasets reveal a similar pattern of change with plant richness declining

278 following a peak at low to moderate chlorophyll, TP or nitrate (James et al., 2005) concentrations. In

279 larger or slightly deeper lakes, macrophytes become restricted to shallower areas with less of the lake

280 containing significant macrophyte beds.

281 An additional development has been to discriminate between effects of nitrogen and phosphorus.

282 Meta-analyses of nutrient enrichment experiments by Elser et al. (2007) have shown that, for algal

283 growth at least, there are about as many instances of nitrogen limitation as of phosphorus limitation

284 and considerably more of co-limitation by both nitrogen and phosphorus. Species richness of submerged

285 macrophyte communities decreases with increasing winter nitrate concentrations (James et al., 2005)

286 and in mesocosm experiments with moderate phosphorus concentrations, growth and diversity of

287 submerged macrophyte communities declined with increasing nitrate loading (Barker et al., 2008). The

288 physiological basis for such effects is poorly understood, although Boedeltje et al., (2005), who,

289 experimentally, observed significantly reduced growth of Potamogeton alpinus at high nitrate

290 concentrations, speculate that nitrate-dominated $\mathrm{N}$ assimilation acts as a carbon and energy drain on

291 plants adapted to ammonia uptake. Macrophyte growth tends to be less strongly related to phosphorus

292 than that of phytoplankton (Lyche-Solheim et al., 2013), because macrophytes have access to

293 phosphorus sources in sediments that elude phytoplankton, which puts greater emphasis on nitrogen

294 supply for macrophytes than for planktonic algae. It is increasingly clear that the hegemony exercised

295 by phosphorus in thinking in this area is misplaced.

296 There have been different estimates of the proportions of lake area that are required to stabilise the

297 plant-dominated system; it could be as low as 10\% (Søndergaard et al., 2010) or as high as 60\% (Blindow

298 et al., 2002), perhaps depending on whether the main stabilising mechanism is via sheltering of

299 invertebrates (whether plant-associated or planktonic) or nutrient sequestration, but the end result of

300 reduced plant cover and diversity is a potentially less stable system. There is equal uncertainty about 
timing of macrophyte growth. Few studies have investigated in detail the seasonal dynamics of

302 macrophyte growth, however, Sayer et al. (2010b) in a study of 39 shallow lakes in the UK and Denmark

303 were able to split lakes into three characteristic groups based on the seasonal abundance of plants in

304 June and August. "Turbid" lakes with few macrophytes, "stable" lakes where plants and clear water

305 were found in both seasons and "crashing" lakes where macrophytes were present in June but not in

306 August when their water became turbid. The "crashing" lakes with a short duration of macrophyte

307 cover were typically dominated by one or more of Potamogeton pectinatus, Potamogeton pusillus and

308 Zanichellia palustris, while those with a long duration of cover had a more diverse macrophyte

309 community. Sayer et al. (2010b) concede that from their study, it is impossible to separate cause from

310 effect. Is the short macrophyte growth-season a response to shading caused by phytoplankton or

311 possibly epiphyte development, or is it the plankton that take advantage of the temporary absence of

312 macrophytes? However, the species involved in the "crashing" lakes are typically associated with higher

313 nutrient concentrations (Kolada et al., 2014); they also die back in winter and may be adapted to a short

314 growing season. This contrasts with the long growth-period and frequent overwintering of charophytes.

315 A very similar set of changes was reported for Lake Müggelsee, in Germany, with the replacement of a

316 diverse charophyte-dominated flora by $P$. pectinatus and Z. palustris and high water transparency in

317 spring, but declining in mid-late summer (Hilt et al., 2013). Thus, as eutrophication progresses, it is

318 possible that the growing season of macrophytes becomes progressively shortened through increases in

319 summer phytoplankton. The boom-bust population dynamics of widespread invasive species, such as

320 Elodea, that tend to dominate in already species-poor eutrophic lakes in Europe may further promote

321 overall instability in plant cover and offer a window for phytoplankton establishment, though whether

322 invasion status affects switching behavior in lakes is presently unknown.

323 Where winter ice cover is frequent, as on the Boreal Plain of western Canada, macrophyte-dominated

324 systems are commonplace, and many lakes are fish-free (Bayley and Prather, 2003). However, using a 
combination of remote sensing and ground survey covering a 20-year period, Bayley et al. (2007)

326 demonstrated that the majority of these lakes show relatively frequent changes between macrophyte

327 and plankton-dominated states. Most of the lakes in the region had concentrations of TP from 25-100

$328 \mu \mathrm{g} \mathrm{I}^{-1}$, similar to the range of concentrations over which alternative states are likely to exist (Scheffer and

329 Jeppesen, 1998) and thus, being in a relatively pristine landscape, these lakes may illustrate the

330 mechanisms influencing the successful establishment of macrophytes (Bayley et al., 2007). Owing to the

331 severe winter, these lakes are "reset" each year, with both zooplankton and macrophytes having to re-

332 establish from eggs and propagules during the spring. Although the majority (70\%) of the lakes in any

333 one year were clear, only $20 \%$ remained clear for the whole 20 -year survey period; furthermore, of the

334 unstable lakes, on average $25 \%$ switched in synchrony. All of the lakes were very shallow and should

335 support substantial cover of submerged macrophytes; the fact that in some years they did not, suggests

336 that success of macrophytes was linked to conditions in the spring which could be influenced by local

337 weather, especially rainfall, and possibly the brownness of the water in this peaty landscape. Like the

338 crashing European lakes (Sayer et al., 2010b), these Canadian lakes are species poor (albeit in this case

339 naturally so), increasing the likelihood that adverse weather could have detrimental impacts. Thus, with

340 moderate nutrient levels, the establishment of one or two important species of macrophytes in

341 competition with phytoplankton can be envisaged as a lottery that is loaded according to the availability

342 of plant propagules, eggs of invertebrate grazers, timing of algal growth and local weather conditions.

343 Similar factors are commonly invoked to explain the failure of macrophytes to respond rapidly to

344 improved conditions in restored lakes.

345 There is also evidence of more frequent changes of state in European lakes. Lake Tåkern and Lake

346 Krankesjön in southern Sweden have switched four and three times respectively over the last five

347 decades (Hargeby et al., 2007). Both lakes have spent longer periods dominated by macrophytes than

348 by plankton, with turbid periods persisting on average for only five years, suggesting that the stabilising 
forces in favour of macrophytes were relatively strong. In both cases the transition from turbid to clear

350 state was started by the establishment of the fast-growing canopy-forming macrophytes, $P$. pectinatus

351 or Myriophyllum spicatum, which were later replaced by charophytes, a reverse of the sequence of

352 change from clear to turbid where charophytes were replaced by angiosperms (Blindow, 1992b). There

353 is no clear explanation for these changes, but weather conditions were likely to have been involved. For

354 example, just prior to the most recent shift to turbid conditions in Lake Tåkern an unusually high spring

355 phytoplankton biomass occurred, potentially linked to high rainfall and greater input of nutrients

356 (Hargeby et al., 2007). High water levels in spring in the mid-1970s were also highlighted as a potential

357 explanation for a switch to turbid water (Blindow, 1992b) and low water to a switch back to

358 macrophytes (Blindow et al., 1993). In these lakes, changes in fish populations also took place, as a

359 result of winter fish kills and these are also likely to have influenced conditions. However, the transition

360 to a species-poor, canopy-forming plant assemblage, immediately before and after the switch in states,

361 and the possible influence of weather conditions influencing the light climate via water level changes

362 and plankton growth during the spring, give a very similar picture to that provided by Sayer et al.,

363 (2010a) of a species-poor macrophyte community being squeezed between spring and late summer

364 plankton blooms.

365 The spring clear water phase that occurs in eutrophic lakes (Lampert et al., 1986) is probably a key

366 window for submerged macrophyte establishment. Its existence results from grazing zooplankton and

367 its length and timing can be dependent on weather conditions during the winter and spring, which

368 influence both grazing zooplankton numbers (de Senerpont Domis et al., 2007) and the migratory

369 movement of planktivorous fish as they seek to minimise their own risk of predation by moving out of

370 lakes to tributary streams during winter (Brönmark et al., 2010). The timing and proportion of fish

371 migrating varies between years and can be linked to fish condition, food availability and potentially local

372 climate. Brönmark et al. (2010) offer a speculative model which links clear-water, macrophyte- 
dominated systems to better fish condition, higher winter migration, greater zooplankton survival and a

374 re-enforcement of the spring clear water period, with the opposite true for turbid states. Given the

375 potential for weather to influence these seasonal events and the reliance of canopy-forming

376 macrophyte taxa on regrowth from overwintering propagules (Van den Berg et al., 1999), there is clear

377 potential for a loss of synchrony, potentially driving an already macrophyte-species poor and therefore

378 unstable lake to phytoplankton-dominance. Availability of light for macrophytes is also influenced by

379 water level and several studies have reported stronger growth of macrophytes when water levels were

380 low (Beklioğlu et al., 2006; Bucak et al., 2012; Ejankowski and Solis, 2015). Water level changes,

381 themselves potentially linked to rainfall, or lake management, are thus an additional factor that could

382 control macrophyte development during the spring.

383 There are also indications of regular cyclical growth of macrophytes with a periodicity of 5-7 years (Moss

384 et al., 1990; Blindow et al., 1993; Perrow et al., 1994; Rip et al., 2005). It has been suggested that these

385 changes are linked to the storage and subsequent release of phosphorus due to buildup of organic

386 matter in the sediment which subsequently influences the summer release of phosphorus (Genkai-Kato

387 and Carpenter, 2005; Van Nes et al., 2007) and hence the development of phytoplankton. However, it

388 has been shown that the TP cycle found in Botshol (Rip et al., 2005) can also be accounted for by rainfall

389 patterns (Rip et al., 2007). Hargeby et al., (2006) also noted that the total organic nitrogen concentration

390 in Lake Tåkern oscillated with a periodicity of 8 years during the clear water, macrophyte-dominated

391 period and that this could be cross-correlated to the North Atlantic oscillation (NAO) which might

392 therefore be linked to macrophyte production, although no causative mechanism was identified. In a

393 review of long-term data on macrophyte abundance in several shallow lakes in the Norfolk Broadland,

394 Phillips et al. (2015) noted that lakes more isolated from the rivers, with recovering, (at least

395 temporarily), but species-poor macrophyte communities showed long-term synchronous cycles

396 suggestive of weather-related influences, with peak abundance occurring in warm sunny years. Thus 
there is growing evidence that local weather events can influence the development of macrophytes and

398 the outcome of their competition with algae for light. While this is undoubtedly not a new phenomenon

399 climate change and increased inter-annual variability in weather conditions are likely to raise its

400 importance.

\section{7. Conclusions}

402 Over the last 40 years it has become clear that, when present, macrophytes have a competitive

403 advantage over algae. To that extent the original graphical conceptual model of Phillips et.al, (1978)

404 remains valid. What it did not include were the feedback mechanisms of the grazers and the potential

405 instability that this creates (Figure 1). Provided the macrophyte associated invertebrate grazing fauna,

406 both planktonic and benthic, are intact, this advantage is largely independent of nutrient load. In

407 shallower lakes, macrophytes can occupy a large proportion of the lake basin and, if evergreen taxa such

408 as charophytes dominate, can lock up, at least temporarily, substantial proportions of a lake's

409 phosphorus. However, with increasing nutrient loads the integrity of this system is sensitive to a wide

410 range of stochastic events, many perhaps driven by local weather conditions, which create a window of

411 opportunity for algal growth. The resultant increase in shading filters the macrophyte species pool until

412 only fast-growing canopy-forming or free-floating species persist (Kolada et al., 2014). These remaining

413 macrophytes also become compressed within a seasonally defined "sandwich" (Sayer et al., 2010a) and

414 are ultimately replaced by plankton. The loss of macrophytes from lakes might be better perceived as

415 the gradual erosion of a competitive advantage rather than a sudden switch in state, but with increased

416 nutrient loading it seems inevitable that events will sooner or later conspire to accelerate this loss.

417 Recovery of macrophytes may subsequently be engineered but all the evidence suggests that sustained

418 recovery requires significant reduction in nutrient concentrations (Jeppesen et al., 2012). 
Lakes have traditionally been managed as discrete entities with only intellectual cognizance given to the

420 reality that the unit of management is the catchment. This approach has a long tradition in European

421 conservation and still determines attitudes to terrestrial conservation. It has meant however, that lakes

422 have been seen in isolation, as closed systems and with equilibrium communities that can be managed

423 by suitable manipulation. Such quasi-equilibria may last for some time, perhaps as long as a couple of

424 scientist-career spans, but our increasing understanding is that lakes are very open systems that have

425 always been continually changing in response to natural climatic fluctuations and geological events.

426 Phases of apparent stability in dynamic systems will always prove beguiling and may attract a value if

427 attributes such as aesthetics, rarity or diversity appeal in the context of that period of history. But this

428 value is notional and has little relevance to the long-term march of natural processes. Phillips et al.

429 (1978) began a process of understanding the mechanisms that influence lake state that morphed into a

430 general consideration of particular states and how they were maintained. There are some examples that

431 might fit their original hypothesis and they are of great intellectual interest. But they may cloud a

432 greater picture of change that can be slow or rapid, extensive or subtle and in which simple patterns and

433 hypotheses do not apply. The intense influence of ourselves has made it very difficult to interpret

434 change because changes come in many forms and are sometimes not easily recognized, especially at

435 first, against a background of short-term natural variation, and their causes even less readily diagnosed.

436 Monitoring change where there are no unchanging controls, if any control at all, will always struggle to

437 reveal mechanisms objectively. Experiments can reveal mechanisms but the specific experimental

438 circumstances may capture merely a snapshot of a lake's history. Nonetheless a degree of

439 understanding has been revealed using replicated experimental mesocosms that allow hypothesis-

440 testing, alongside analysis of sediment cores to determine change in a range of chemicals and sub-fossils

441 over centuries, and potentially millennia, though such perspectives have only recently begun to figure in

442 lake management (Sayer et al., 2012). We have used large scale surveys which depend on space-for- 
time substitution and finally a small number of long-term monitoring programmes. All individually have

444 strengths and weaknesses, but in combination they have delivered an understanding of shallow lakes

445 and the central role that submerged macrophytes play in their ecology. It is the diversity of the positive

446 feedback pathways that macrophytes provide, and the different time scales and evolving background

447 against which these operate (Scheffer and van Nes, 2007) that make it impossible to provide a simple

448 all-encompassing mechanistic model relating macrophyte loss to eutrophication. Given that

449 eutrophication itself represents a syndrome of co-occurring pressures, such simplicity must always be

450 questioned.

451 References

452 Bakker, E.S., Nolet, B.A., 2014. Experimental evidence for enhanced top-down control of freshwater 453 macrophytes with nutrient enrichment. Oecologia 176, 825-836.

454 Bakker, E.S., Sarneel, J.M., Gulati, R.D., Liu, Z., van Donk, E., 2012. Restoring macrophyte diversity in 455 shallow temperate lakes: biotic versus abiotic constraints. Hydrobiologia 710, 23-37.

456 Bales, M., Moss, B., Phillips, G., Irvine, K., Stansfield, J., 1993. The changing ecosystem of a shallow, 457 brackish lake, Hickling Broad, Norfolk, U.K. II. Long-term trends in water chemistry and ecology and their 458 implications for restoration of the lake. Freshwat. Biol. 29, 141-165.

459 Balls, H., Moss, B., Irvine, K., 1989. The loss of submerged plants with eutrophication I. Experimental 460 design, water chemistry, aquatic plant and phytoplankton biomass in experiments carried out in ponds 461 in the Norfolk Broadland. Freshwat. Biol. 22, 71-87.

462 Barker, T., Hatton, K., O'Connor, M., Connor, L., Moss, B., 2008. Effects of nitrate load on submerged 463 plant biomass and species richness: results of a mesocosm experiment. Arch. Hydrobiol. 173, 89-100. 
Bayley, S.E., Creed, I.F., Sass, G.Z., Wong, A.S., 2007. Frequent regime shifts in trophic states in shallow

465 lakes on the Boreal Plain: Alternative "unstable" states? Limnol. Oceanogr. 52, 2002-2012.

466 Bayley, S.E., Prather, C.M., 2003. Do wetland lakes exhibit alternative stable states? Submersed aquatic

467 vegetation and chlorophyll in western boreal shallow lakes. Limnol. Oceanogr. 48, 2335-2345.

468 Bécares, E., Gomá, J., Fernández-Aláez, M., Fernández-Aláez, C., Romo, S., Miracle, M.R., Ståhl-Delbanco,

469 A., Hansson, L.-A., Gyllström, M., Van de Bund, W.J., Van Donk, E., Kairesalo, T., Hietala, J., Stephen, D.,

470 Balayla, D., Moss, B., 2007. Effects of nutrients and fish on periphyton and plant biomass across a

471 European latitudinal gradient. Aquat. Ecol. 42, 561-574.

472 Beklioğlu, M., Altinayar, G., Tan, C.O., 2006. Water level control over submerged macrophyte

473 development in five shallow lakes of Mediterranean Turkey. Arch. Hydrobiol. 166, 535-556.

474 Bender, E.A., Case, T.J., Gilpin, M.E., 1984. Perturbation experiments in community ecology: Theory and 475 practice. Ecology 65, 1-13.

476 Beresford, A.L., Jones, J.I., 2010. Weedbeds and big bugs: the importance of scale in detecting the

477 influence of nutrients and predation on macroinvertebrates in plant-dominated shallow lakes. Freshwat.

478 Biol. 55, 514-530.

479 Blindow, I., 1992a. Decline of charophytes during eutrophication: comparison with angiosperms.

480 Freshwat. Biol. 28, 9-14.

481 Blindow, I., 1992b. Long- and short-term dynamics of submerged macrophytes in two shallow eutrophk 482 lakes. Freshwat. Biol. 28, 15-27.

483 Blindow, I., Andersson, G., Hargeby, A., Johansson, S., 1993. Long-term pattern of alternative stable 484 states in two shallow eutrophic lakes. Freshwat. Biol. 30, 159-167. 
Blindow, I., Hargeby, A., Andersson, G., 2002. Seasonal changes of mechanisms maintaining clear water

486 in a shallow lake with abundant Chara vegetation. Aquat. Bot. 72, 315-334.

487 Blindow, I., Hargeby, A., Meyercordt, J., Schubert, H., 2006. Primary production in two shallow lakes with 488 contrasting plant form dominance: A paradox of enrichment? Limnol. Oceanogr. 51, 2711-2721.

489 Boedeltje, G. Smolders, AJP Roelofs, J.G.M., 2005. Combined effects of water column nitrate

490 enrichment, sediment type and irradiance on growth and foliar nutrient concentrations of Potamogeton

491 alpinus. Freshwat. Biol. 50, 1537-1547

492 Boorman, L.A., Fuller, R.M., 1981. The Changing Status of Reedswamp in the Norfolk Broads. J. Appl.

493 Ecol. 18, 241-269.

494 Brodersen, K.P., Odgaard, B.V., Vestergaard, O., Anderson, N.J., 2001. Chironomid stratigraphy in the 495 shallow and eutrophic Lake Søbygaard, Denmark: chironomid-macrophyte co-occurrence. Freshwat. 496 Biol. 46, 253-267.

497 Brönmark, C., 1985. Interactions between macrophytes, epiphytes and herbivores: An experimental 498 approach. Oikos 45, 26-30.

499 Brönmark, C., 1994. Effects of Tench and Perch on interactions in a freshwater, benthic food chain. $500 \quad$ Ecology 75, 1818-1828.

501 Brönmark, C., Brodersen, J., Chapman, B., Nicolle, A., Nilsson, P., Skov, C., Hansson, L.-A., 2010. Regime 502 shifts in shallow lakes: the importance of seasonal fish migration. Hydrobiologia 646, 91-100.

503 Brönmark, C., Klosiewski, S.P., Stein, R.A., 1992. Indirect effects of predation in a freshwater, benthic 504 food chain. Ecology 73, 1662-1674.

505 Brönmark, C., Weisner, S.E.B., 1992. Indirect effects of fish community structure on submerged 506 vegetation in shallow, eutrophic lakes: an alternative mechanism. Hydrobiologia 243-244, 293-301. 
Bucak, T., Saraoğlu, E.C.E., Levi, E.E., Nihan, T., İdil Çakiroğlu, A., Jeppesen, E., Beklioğlu, M., 2012. The

508 influence of water level on macrophyte growth and trophic interactions in eutrophic Mediterranean

509 shallow lakes: a mesocosm experiment with and without fish. Freshwat. Biol. 57, 1631-1642.

510 Burks, R.L., Mulderij, G., Gross, E., Jones, I., Jacobsen, L., Jeppesen, E., Van Donk, E., 2006, Center stage:

511 The crucial role of macrophytes in regulating trophic interactions in shallow lake wetlands. In: Bobbink,

512 R., Beltman, B., Verhoeven, J.T.A., Whigham, D.F. (Eds.), Wetlands: Functioning, Biodiversity

513 Conservation, and Restoration, pp. 37-59.

514 Carvalho, L., 1994. Top-down control of phytoplankton in a shallow hypertrophic lake - Little-Mere

515 (England). Hydrobiologia 275, 53-63.

516 Cattaneo, A., Kalff, J., 1980. The relative contribution of aquatic macrophytes and their epiphytes to the

517 production of macrophyte beds. Limnol. Oceanogr. 25, 280-289.

518 Chambers, P.A., Kalff, J., 1985. Depth distribution and biomass of submersed aquatic macrophyte

519 communities in relation to Secchi depth. Can. J. Fish. Aquat. Sci. 42, 701-709.

520 Daldorph, P.W.G., Thomas, J.D., 1995. Factors influencing the stability of nutrient-enriched freshwater 521 macrophyte communities: the role of sticklebacks Pungitius pungitius and freshwater snails. Freshwat.

522 Biol. 33, 271-289.

523 Davidson, T.A., Sayer, C.D., Bennion, H., David, C., Rose, N., Wade, M.P., 2005. A 250 year comparison of 524 historical, macrofossil and pollen records of aquatic plants in a shallow lake. Freshwat. Biol. 50, 16715251686.

526 de Senerpont Domis, L.N., Mooij, W.M., Hulsmann, S., van Nes, E.H., Scheffer, M., 2007. Can

527 overwintering versus diapausing strategy in Daphnia determine match-mismatch events in zooplankton528 algae interactions? Oecologia 150, 682-698. 
Diehl, S., Kornijow, R., 1998, Influence of submerged macrophytes on trophic interactions among fish

530 and macroinvertebrates. In: Jeppesen, E., Søndergaard, M., Søndergaard, M., Christoffersen, K. (Eds.),

531 Structuring Role of Submerged Macrophytes in Lakes, pp. 24-46.

532 Ejankowski, W., Solis, M., 2015. Response of Hormwort (Ceratophyllum demersum L.) to water level

533 drawdown in a turbid water reservoir. Appl. Ecol. Environ. Res. 13, 219-228.

534 Elger, A., Willby, N.J., Cabello-Martinez, M., 2009. Invertebrate grazing during the regenerative phase

535 affects the ultimate structure of macrophyte communities. Freshwat. Biol. 54, 1246-1255.

536 Elser, J.J., Bracken, M.E., Cleland, E.E., Gruner, D.S., Harpole, W.S., Hillebrand, H., Ngai, J.T., Seabloom,

537 E.W., Shurin, J.B., Smith, J.E., 2007. Global analysis of nitrogen and phosphorus limitation of primary

538 producers in freshwater, marine and terrestrial ecosystems. Ecol. Lett. 10, 1135-1142.

539 Eminson, D., Moss, B., 1980. The composition and ecology of periphyton communities in freshwaters: 1

540 The influence of host type and external environment on community composition. Brit. Phycol. J. 15, 429-

541446.

542 Eminson, D., Phillips, G., 1978. Laboratory experiment to examine the effects of nutrient enrichment on 543 macrophyte and epiphyte growth. Verh. int. Ver. Limnol. 20, 82-87..

544 Feuchtmayr, H., Moran, R., Hatton, K., Connor, L., Heyes, T., Moss, B., Harvey, I., Atkinson, D., 2009.

545 Global warming and eutrophication: effects on water chemistry and autotrophic communities in

546 experimental hypertrophic shallow lake mesocosms. J. Appl. Ecol. 46, 713-723.

547 Gayet, G., Guillemain, M., Fritz, H., Mesleard, F., Begnis, C., Costiou, A., Body, G., Curtet, L., Broyer, J.,

548 2011. Do mute swan (Cygnus olor) grazing, swan residence and fishpond nutrient availability

549 interactively control macrophyte communities? Aquat. Bot. 95, 110-116. 
Genkai-Kato, M., Carpenter, S.R., 2005. Eutrophication due to phosphorus recycling in relation to lake

551 morphometry, temperature, and macrophytes. Ecology 86, 210-219.

552 Gosling, L., 1974. The coypu in East Anglia. Trans. Norfolk Norwich Nat. Soc. 23, 49-59.

553 Gross, E.M., Hilt, S., Lombardo, P., Mulderij, G., 2007. Searching for allelopathic effects of submerged

554 macrophytes on phytoplankton-state of the art and open questions. Hydrobiologia 584, 77-88.

555 Hall, D.J., Ehlinger, T.J., 1989. Perturbation, planktivory, and pelagic community structure - the

556 consequence of winterkill in a small lake. Can. J. Fish. Aquat. Sci. 46, 2203-2209.

557 Hansson, L.-A., Nicolle, A., Brönmark, C., Hargeby, A., Lindström, Å., Andersson, G., 2010. Waterfowl, 558 macrophytes, and the clear water state of shallow lakes. Hydrobiologia 646, 101-109.

559 Hansson, L.A., 1988. Effects of competitive interactions on the biomass development of planktonic and 560 periphytic algae in lakes. Limnol. Oceanogr. 33, 121-128.

561 Hargeby, A., Andersson, G., Blindow, I., Johansson, S., 1994. Trophic web structure in a small shallow 562 eutrophic lake during a dominance shift from phytoplankton to submerged macrophtyes. Hydrobiologia $563279,83-90$.

564 Hargeby, A., Blindow, I., Andersson, G., 2007. Long-term Patterns of Shifts between Clear and Turbid 565 States in Lake Krankesjön and Lake Tåkern. Ecosystems 10, 29-36.

566 Hargeby, A., Jonzén, N., Blindow, I., 2006. Does a long-term oscillation in nitrogen concentration reflect 567 climate impact on submerged vegetation and vulnerability to state shifts in a shallow lake? Oikos 115 , $568 \quad 334-348$.

569 Hilt, S., 2006. Recovery of Potamogeton pectinatus L. stands in a shallow eutrophic lake under extreme 570 grazing pressure. Hydrobiologia 570, 95-99. 
571 Hilt, S., Gross, E.M., Hupfer, M., Morscheid, H., Mählmann, J., Melzer, A., Poltz, J., Sandrock, S., Scharf,

572 E.-M., Schneider, S., van de Weyer, K., 2006. Restoration of submerged vegetation in shallow eutrophic

573 lakes - A guideline and state of the art in Germany. Limnologica 36, 155-171.

574 Hilt, S., Köhler, J., Adrian, R., Monaghan, M.T., Sayer, C.D., 2013. Clear, crashing, turbid and back - long-

575 term changes in macrophyte assemblages in a shallow lake. Freshwat. Biol. 58, 2027-2036.

576 Ibelings, B.W., Portielje, R., Lammens, E.H.R.R., Noordhuis, R., van den Berg, M.S., Joosse, W., Meijer,

577 M.L., 2007. Resilience of alternative stable states during the recovery of shallow lakes from

578 eutrophication: Lake Veluwe as a case study. Ecosystems 10, 4-16.

579 Irvine, K., Moss, B., Balls, H., 1989. The loss of submerged plants with eutrophication II. Relationships 580 between fish and zooplankton in a set of experimental ponds, and conclusions. Freshwat. Biol. 22, 89-

581107.

582 Isermann, D.A., Chipps, S.R., Brown, M.L., 2004. Seasonal Daphnia biomass in winterkill and

583 nonwinterkill glacial lakes of South Dakota. N. Am. J. Fish. Manage. 24, 287-292.

584 James, C., Fisher, J., Russell, V., Collings, S., Moss, B., 2005. Nitrate availability and hydrophyte species 585 richness in shallow lakes. Freshwat. Biol. 50, 1049-1063.

586 Jeppesen, E., Jensen, J., Søndergaard, M., Lauridsen, T., Pedersen, L., Jensen, L., 1997. Top-down control 587 in freshwater lakes: the role of nutrient state, submerged macrophytes and water depth. Hydrobiologia $588 \quad 342-343,151-164$.

589 Jeppesen, E., Jensen, J.P., Jensen, C., Faafeng, B., Hessen, D.O., Søndergaard, M., Lauridsen, T., Brettum, 590 P., Christoffersen, K., 2003. The impact of nutrient state and lake depth on top-down control in the 591 pelagic zone of lakes: A study of 466 lakes from the temperate zone to the Arctic. Ecosystems 6, 313592325. 
Jeppesen, E., Peder Jensen, J., Søndergaard, M., Lauridsen, T., Landkildehus, F., 2000. Trophic structure, 594 species richness and biodiversity in Danish lakes: changes along a phosphorus gradient. Freshwat. Biol. 45, 201-218.

Jeppesen, E., Søndergaard, M., Jensen, J.P., Mortensen, E., Hansen, A.-M., Jørgensen, T., 1998a.

597 Cascading trophic interactions from fish to bacteria and nutrients after reduced sewage loading: An 18-

598 year study of a shallow hypertrophic lake. Ecosystems 1, 250-267.

599 Jeppesen, E., Søndergaard, M., Lauridsen, T.L., Davidson, T.A., Liu, Z., Mazzeo, N., Trochine, C., Özkan, K., 600 Jensen, H.S., Trolle, D., Starling, F., Lazzaro, X., Johansson, L.S., Bjerring, R., Liboriussen, L., Larsen, S.E., 601 Landkildehus, F., Egemose, S., Meerhoff, M., 2012. Biomanipulation as a restoration tool to combat 602 eutrophication: Recent adcances and future challenges. Adv. Ecol. Res. 47, 411-488.

603 Jeppesen, E., Søndergaard, M., Søndergaard, M., Christofferson, K., 1998b, The structuring role of 604 submerged macrophytes in lakes. Ecological Studies, Vol. 131. Springer, New York, 423 pp.

605 Jones, J.I., Moss, B., Eaton, J.W., Young, J.O., 2000. Do submerged aquatic plants influence periphyton 606 community composition for the benefit of invertebrate mutualists? Freshwat. Biol. 43, 591-604.

607 Jones, J.I., Sayer, C.D., 2003. Does the fish-invertebrate-periphyton cascade precipitate plant loss in 608 shallow lakes? Ecology 84, 2155-2167.

609 Jones, J.I., Young, J.O., Eaton, J.W., Moss, B., 2002. The influence of nutrient loading, dissolved inorganic 610 carbon and higher trophic levels on the interaction between submerged plants and periphyton. J. Ecol. $61190,12-24$.

612 Jones, J.I., Young, J.O., Haynes, G.M., Moss, B., Eaton, J.W., Hardwick, K.J., 1999. Do submerged aquatic 613 plants influence their periphyton to enhance the growth and reproduction of invertebrate mutualists? 614 Oecologia 120, 463-474. 

macrophytes in Danish lakes to nutrient loading reductions and biomanipulation. Hydrobiologia 506-

Kolada, A., Willby, N., Dudley, B., Nõges, P., Søndergaard, M., Hellsten, S., Mjelde, M., Penning, E., van Geest, G., Bertrin, V., Ecke, F., Mäemets, H., Karus, K., 2014. The applicability of macrophyte compositional metrics for assessing eutrophication in European lakes. Ecol. Indicators 45, 407-415.

Kornijów, R., Measey, G.J., Moss, B., 2016. The structure of the littoral: effects of waterlily density and perch predation on sediment and plant-associated macroinvertebrate communities. Freshwat. Biol. 61, $32-50$.

Kosten, S., Kamarainen, A.M.Y., Jeppesen, E., Van Nes, E.H., Peeters, E.T.H.M., Mazzeo, N., Sass, L., Hauxwell, J., Hansel-Welch, N., Lauridsen, T.L., Søndergaard, M., Bachmann, R.W., Lacerot, G., Scheffer, M., 2009. Climate-related differences in the dominance of submerged macrophytes in shallow lakes. Global Change Biol. 15, 2503-2517.

Kufel, L., Kufel, I., 2002. Chara beds acting as nutrient sinks in shallow lakes-a review. Aquat. Bot. 72, 249-260.

Lalonde, S., Downing, J.A., 1991. Epiphyton biomass is related to lake trophic status, depth and macrophyte architecture. Can. J. Fish. Aquat. Sci. 48, 2285-2291.

Lambert, D., Cattaneo, A., Carignan, R., 2008. Periphyton as an early indicator of perturbation in recreational lakes. Can. J. Fish. Aquat. Sci. 65, 258-265.

Lampert, W., Fleckner, W., Rai, H., Taylor, B.E., 1986. Phytoplankton control by grazing zooplankton - A study on the spring clear-water phase. Limnol. Oceanogr. 31, 478-490.

Lauridsen, T., Peder Jensen, J., Jeppesen, E., Søndergaard, M., 2003. Response of submerged $635509,641-649$. 
636

637 638

Lauridsen, T.L., Jeppesen, E., Andersen, F. Ø., 1993. Colonization of submerged macrophytes in shallow fish manipulated Lake Væng: impact of sediment composition and waterfowl grazing. Aquat. Bot. 46, 115.

Leah, R., Moss, B., Forrest, D., 1980. The role of predation in causing major changes in the limnology of a hyper-eutrophic lake. Int. Rev. ges. Hydrobiol. Hydrogr. 65, 223-247.

Liboriussen, L., Jeppesen, E., 2006. Structure, biomass, production and depth distribution of periphyton on artificial substratum in shallow lakes with contrasting nutrient concentrations. Freshwat. Biol. 51, 95109.

Liboriussen, L., Jeppesen, E., Bramm, M., Lassen, M., 2005. Periphyton-macroinvertebrate interactions in light and fish manipulated enclosures in a clear and a turbid shallow lake. Aquat. Ecol. 39, 23-39.

Lodge, D.M., 1991. Herbivory on freshwater macrophytes. Aquat. Bot. 41, 195-224.

Lyche-Solheim, A., Feld, C.K., Birk, S., Phillips, G., Carvalho, L., Morabito, G., Mischke, U., Willby, N., Søndergaard, M., Hellsten, S., Kolada, A., Mjelde, M., Böhmer, J., Miler, O., Pusch, M.T., Argillier, C., Jeppesen, E., Lauridsen, T.L., Poikane, S., 2013. Ecological status assessment of European lakes: a comparison of metrics for phytoplankton, macrophytes, benthic invertebrates and fish. Hydrobiologia 704, 57-74.

Madgwick, G., Emson, D., Sayer, C.D., Willby, N.J., Rose, N.L., Jackson, M.J., Kelly, A., 2011. Centennialscale changes to the aquatic vegetation structure of a shallow eutrophic lake and implications for restoration. Freshwat. Biol. 56, 2620-2636.

Martin, T.H., Crowder, L.B., Dumas, C.F., Burkholder, J.M., 1992. Indirect effects of fish on macrophytes in Bays Mountain Lake: Evidence for a littoral trophic cascade. Oecologia 89, 476-481.

Mason, C.F., Bryant, R.J., 1975. Changes in the ecology of the Norfolk Broads. Freshwat. Biol. 5, 257-270. 
672

673

674

675

676

677 678

Mazumder, A., Taylor, W.D., McQueen, D.J., Lean, D.R.S., 1989. Effects of nutrients and grazers on periphyton phosphorus in lake enclosures. Freshwat. Biol. 22, 405-415.

McKee, D., Hatton, K., Eaton, J.W., Atkinson, D., Atherton, A., Harvey, I., Moss, B., 2002. Effects of simulated climate warming on macrophytes in freshwater microcosm communities. Aquat. Bot. 74, 7183.

Middelboe, A.L., Markager, S., 1997. Depth limits and minimum light requirements of freshwater macrophytes. Freshwat. Biol. 37, 553-568.

Mills, L.J., Chichester, C., 2005. Review of evidence: are endocrine-disrupting chemicals in the aquatic environment impacting fish populations? Sci. Total Environ. 343, 1-34.

Mitchell, S.F., 1989. Primary production in a shallow eutrophic lake dominated alternately by phytoplankton and by submerged macrophytes. Aquat. Bot. 33, 101-110.

Morgan, N.C., 1970. Changes in the fauna and flora of a nutrient enriched lake. Hydrobiologia 35, 545553.

Moss, B., 1976. The effects of fertilization and fish on community structure and biomass of aquatic macrophytes and epiphytic algal populations: An ecosystem experiment. J. Ecol. 64, 313-342.

Moss, B., 1983. The Norfolk Broadland: Experiments in the restoration of a complex wetland. Biol. Rev. $58,521-561$.

Moss, B., 2007. Lakes and society: Mirrors to our past, present and future. Lake Reserv. Manage. 23, 457-465.

Moss, B., 2015. Mammals, freshwater reference states, and the mitigation of climate change. Freshwat. Biol. 60, 1964-1976.. 
679 Moss, B., Carvalho, L., Plewes, J., 2002. The lake at Llandrindod Wells - a restoration comedy? Aquat.

680 Conserv.: Mar. Freshwat. Ecosyst. 12, 229-245.

681 Moss, B., Madgwick, J., Phillips, G., 1996a, Guide to the Restoration of nutrient-enriched shallow lakes.

682 Broads Authority.

683 Moss, B., Ryszard, K., Measey, G.J., 1998. The effects of nymphaeid (Nuphar lutea) density and predation 684 by perch (Perca fluviatilis) on the zooplankton communities in a shallow lake. Freshwat. Biol. 39, 689685697.

686 Moss, B., Stansfield, J., Irvine, K., 1990. Problems in the restoration of a hypertrophic lake by diversion of 687 a nutrient-rich inflow. Verh. Int. Ver. Limnol. 24, 409-425.

688 Moss, B., Stansfield, J., Irvine, K., Perrow, M., Phillips, G., 1996b. Progressive restoration of a shallow 689 lake: A 12-year experiment in isolation, sediment removal and biomanipulation. J. Appl. Ecol. 33, 71-86.

690 Ozimek, T., Vandonk, E., Gulati, R.D., 1993. Growth and nutrient uptake by two species of Elodea in 691 experimental conditions and their role in nutrient accumulation in a macrophyte-dominated lake. 692 Hydrobiologia 251, 13-18.

693 Perrow, M., Moss, B., Stansfield, J., 1994, Trophic interactions in a shallow lake following a reduction in 694 nutrient loading: a long-term study. In: Mortensen, E., Jeppesen, E., Søndergaard, M., Nielsen, L.K. 695 (Eds.), Nutrient Dynamics and Biological Structure in Shallow Freshwater and Brackish Lakes. Springer 696 Netherlands, pp. 43-52.

697 Phillips, G., Bennion, H., Perrow, M., Sayer, C.D., Spears, B., Willby, N., 2015, A review of lake restoration 698 practices and their performance in the Broads National Park, 1980-2013. Report for the Broads 699 Authority, Norwich and Natural England. 
Phillips, G.L., Eminson, D., Moss, B., 1978. A mechanism to account for macrophyte decline in progressively eutrophicated freshwaters. Aquat. Bot. 4, 103-126.

Prigioni, C., Balestrieri, A., Remonti, L., 2005. Food habits of the coypu, Myocastor coypus, and its impact on aquatic vegetation in a freshwater habitat of NW Italy. Folia Zool. 54, 269-277.

Randsalu-Wendrup, L., Conley, D.J., Carstensen, J., Hansson, L.-A., Brönmark, C., Fritz, S.C., Choudhary, P., Routh, J., Hammarlund, D., 2014. Combining limnology and palaeolimnology to investigate recent 706 regime shifts in a shallow, eutrophic lake. J. Paleolimnol. 51, 437-448.

Rip, W.J., Ouboter, M., van Nes, E.H., Beltman, B., 2005. Oscillation of a shallow lake ecosystem upon 708 reduction in external phosphorus load. Arch. Hydrobiol. 164, 387-409.

Rip, W.J., Ouboter, M.R.L., Los, H.J., 2007. Impact of climatic fluctuations on Characeae biomass in a 710 shallow, restored lake in The Netherlands. Hydrobiologia 584, 415-424.

711 Rip, W.J., Rawee, N., de Jong, A., 2006. Alternation between clear, high-vegetation and turbid, low712 vegetation states in a shallow lake: the role of birds. Aquat. Bot. 85, 184-190.

713 Roberts, E., Kroker, J., Körner, S., Nicklisch, A., 2003. The role of periphyton during the re-colonization of 714 a shallow lake with submerged macrophytes. Hydrobiologia 506-509, 525-530.

715 Sand-Jensen, K., Borum, J., 1984. Epiphyte shading and its effect on photosynthesis and diel metabolism 716 of Lobelia dortmanna L. during the spring bloom in a danish lake. Aquat. Bot. 20, 109-119.

717 Sand-Jensen, K., Borum, J., 1991. Interactions among phytoplankton, periphyton, and macrophytes in 718 temperate freshwaters and estuaries. Aquat. Bot. 41, 137-175.

719 Sand-Jensen, K., Madsen, T.V., 1991. Minimum light requirements of submerged freshwater 720 macrophytes in laboratory growth experiments. J. Ecol. 79, 749-764. 
721 Sand-Jensen, K., Riis, T., Vestergaard, O., Larsen, S.E., 2000. Macrophyte decline in Danish lakes and

722 streams over the past 100 years. J. Ecol. 88, 1030-1040.

723 Sand-Jensen, K., Søndergaard, M., 1981. Phytoplankton and epiphyte development and their shading

724 effect on submerged macrophytes in lakes of different nutrient status. Int. Rev. Gesamt. Hydrobiol. 66, $725 \quad 529-552$.

726 Sayer, C.D., Bennion, H., Davidson, T.A., Burgess, A., Clarke, G., Hoare, D., Frings, P., Hatton-Ellis, T.,

727 2012. The application of palaeolimnology to evidence-based lake management and conservation:

728 examples from UK lakes. Aquat. Conserv.: Mar. Freshwat. Ecosyst. 22, 165-180.

729 Sayer, C.D., Burgess, A.M.Y., Kari, K., Davidson, T.A., Peglar, S., Yang, H., Rose, N., 2010a. Long-term 730 dynamics of submerged macrophytes and algae in a small and shallow, eutrophic lake: implications for 731 the stability of macrophyte-dominance. Freshwat. Biol. 55, 565-583.

732 Sayer, C.D., Davidson, T.A., Jones, J.I., 2010b. Seasonal dynamics of macrophytes and phytoplankton in 733 shallow lakes: a eutrophication-driven pathway from plants to plankton? Freshwat. Biol. 55, 500-513.

734 Sayer, C.D., Hoare, D.J., Simpson, G.L., Henderson, A.C.G., Liptrot, E.R., Jackson, M.J., Appleby, P.G., 735 Boyle, J.F., Jones, J.I., Waldock, M.J., 2006. TBT causes regime shift in shallow lakes. Environ. Sci.

736 Technol. 40, 5269-5275.

737 Scheffer, M., Hosper, S.H., Meijer, M.L., Moss, B., Jeppesen, E., 1993. Alternative equilibria in shallow 738 lakes. Trends Ecol. Evol. 8, 275-279.

739 Scheffer, M., Jeppesen, E., 1998, Alternative stable states. In: Jeppesen, E., Sondergaard, M., 740 Søndergaard, M., Christoffersen, K. (Eds.), Structuring Role of Submerged Macrophytes in Lakes, pp. $741 \quad 397-406$. 
742 Scheffer, M., van Nes, E.H., 2007. Shallow lakes theory revisited: various alternative regimes driven by

743 climate, nutrients, depth and lake size. Hydrobiologia 584, 455-466.

744 Schriver, P.E.R., Bøgestrand, J., Jeppesen, E., Søndergaard, M., 1995. Impact of submerged macrophytes

745 on fish-zooplanl phytoplankton interactions: large-scale enclosure experiments in a shallow eutrophic

746 lake. Freshwat. Biol. 33, 255-270.

747 Søndergaard, M., Bruun, L., Lauridsen, T., Jeppesen, E., Madsen, T.V., 1996. The impact of grazing

748 waterfowl on submerged macrophytes: In situ experiments in a shallow eutrophic lake. Aquat. Bot. 53,

749 73-84.

750 Søndergaard, M., Jeppesen, E., Lauridsen, T.L., Skov, C., Van Nes, E.H., Roijackers, R., Lammens, E.,

751 Portielje, R.O.B., 2007. Lake restoration: successes, failures and long-term effects. J. Appl. Ecol. 44, 1095-

7521105.

753 Søndergaard, M., Johansson, L.S., Lauridsen, T.L., Jørgensen, T.B., Liboriussen, L., Jeppesen, E., 2010.

754 Submerged macrophytes as indicators of the ecological quality of lakes. Freshwat. Biol. 55, 893-908.

755 Søndergaard, M., Phillips, G., Hellsten, S., Kolada, A., Ecke, F., Mäemets, H., Mjelde, M., Azzella, M.,

756 Oggioni, A., 2013. Maximum growing depth of submerged macrophytes in European lakes.

757 Hydrobiologia 704, 165-177.

758 South, A.B., Rushton, S.P., Macdonald, D.W., Fuller, R., 2001. Reintroduction of the European beaver

759 (Castor fiber) to Norfolk, UK: a preliminary modelling analysis. J. Zool. 254, 473-479.

760 Spence, D.H.N., Chrystal, J., 1970. Photosynthesis and zonation of freshwater macrophytes I. Depth

761 distribution and shade tolerance. New Phytol. 69, 205-215. 
764 Authority and Environment Agency, Norwich, p. 68.

765 Stansfield, J., Moss, B., Irvine, K., 1989. The loss of submerged plants with eutrophication III. Potential 766 role of organochlorine pesticides: a palaeoecological study. Freshwat. Biol. 22, 109-132.

767 Tátrai, I., Boros, G., György, Á.I., Mátyás, K., Korponai, J., Pomogyi, P., Havasi, M., Kucserka, T., 2008.

768 Abrupt shift from clear to turbid state in a shallow eutrophic, biomanipulated lake. Hydrobiologia 620, 769 149-161.

770 Timms, R.M., Moss, B., 1984. Prevention of growth of potentially dense phytoplankton populations by 771 zooplankton grazing, in the presence of zooplanktivorous fish, in a shallow wetland ecosystem. Limnol.

772 Oceanogr. 29, 472-486.

773 Uhlmann, D., 1980, Stability and multiple steady states of hypereutrophic ecosystems. Hypertrophic 774 ecosystems. Springer, pp. 235-247.

775 Underwood, G.J.C., 1991. Growth enhancement of the macrophyte Ceratophyllum demersum in the 776 presence of the snail Planorbis planorbis: the effect of grazing and chemical conditioning. Freshwat. Biol. $777 \quad 26,325-334$.

778 Underwood, G.J.C., Thomas, J.D., Baker, J.H., 1992. An Experimental Investigation of Interactions in 779 Snail-Macrophyte-Epiphyte Systems. Oecologia 91, 587-595.

780 Van-Donk, E., Gulati, R.D., ledema, A., Meulemans, J.T., 1993. Macrophyte related shifts in the nitrogen 781 and phosphorus contents of the different trophic levels in a biomanipulated shallow lake. Hydrobiologia $782 \quad 251,19-26$. 
Van den Berg, M., Scheffer, M., Van Nes, E., Coops, H., 1999. Dynamics and stability of Chara sp. and

Potamogeton pectinatus in a shallow lake changing in eutrophication level. Hydrobiologia 408-409, 335-

Van Donk, E., Van de Bund, W.J., 2002. Impact of submerged macrophytes including charophytes on phyto- and zooplankton communities: allelopathy versus other mechanisms. Aquat. Bot. 72, 261-274.

Van Nes, E.H., Rip, W.J., Scheffer, M., 2007. A Theory for Cyclic Shifts between Alternative States in Shallow Lakes. Ecosystems 10, 17-28.

Willby, N.J. \& Eaton, J.W., 1996. Backwater habitats and their role in nature conservation on navigable waterways. Hydrobiologia 340, 333-338.

Willby, N., Pitt, J., Phillips, G., 2012, The ecological classification of UK lakes using aquatic macrophytes.

793 Environment Agency, Bristol. Available from https://www.gov.uk/government/publications/the-

794 ecological-classification-of-uk-lakes-using-aquatic-macrophytes. Accessed 4 January 2016.

795 Willby, N.J., Perfect, C., Law, A., 2014, The Scottish Beaver Trial: Monitoring of aquatic vegetation and 796 associated features of the Knapdale lochs 2008-2013, final report. Scottish Natural Heritage

797 Commissioned Report No 688. Available from http://www.snh.gov.uk/publications-data-and798 research/publications/search-the-catalogue/publication-detail/?id=2187. Accessed 30 December 2015.

799 Wilsey, B.J., Chabreck, R.H., Linscombe, R.G., 1991. Variation in nutria diets in selected freshwater 800 forested wetlands of Louisiana. Wetlands 11, 263-278.

801 Wood, K.A., Stillman, R.A., Clarke, R.T., Daunt, F., O'Hare, M.T., 2012. The impact of waterfowl herbivory 802 on plant standing crop: a meta-analysis. Hydrobiologia 686, 157-167.

803 Woollhead, J., 1994. Birds in the trophic web of Lake Esrom, Denmark. Hydrobiologia 279, 29-38. 
804 Zambrano, L., Hinojosa, D., 1999. Direct and indirect effects of carp (Cyprinus carpio L.) on macrophyte 805 and benthic communities in experimental shallow ponds in central Mexico. Hydrobiologia 408-409, 131806138.

807 Zambrano, L., Perrow, M.R., Sayer, C.D., Tomlinson, M.L., Davidson, T.A., 2006. Relationships between 808 fish feeding guild and trophic structure in English lowland shallow lakes subject to anthropogenic 809 influence: implications for lake restoration. Aquat. Ecol. 40, 391-405.

810 Zambrano, L., Scheffer, M., Martínez-Ramos, M., 2001. Catastrophic response of lakes to benthivorous 811 fish introduction. Oikos 94, 344-350. 
Figure caption: Major interactions in shallow lake ecosystems. The left hand diagram summarises interactions in clear water, macrophyte-dominated lakes, the right hand diagram shows interactions in turbid-water algal-dominated lakes. Pressures on different ecosystem components that may trigger a sudden or gradual shift to algal dominance are shown in the central column. In addition to these pressures interannual variation in water temperature, water depth and sunshine hours will strengthen or weaken particular interactions by affecting, for example, year class strength in fish, hatching dates in zooplankton and the onset of growth in macrophytes. Symbols show the direction of the effect and arrows show the magnitude of the effect. The bottom half of each diagram focuses on bottom up effects related to nutrients. The top half of each diagram shows topdown effects. Dashed arrows show other effects including allelopathy, nutrient sequestering, shading, bioturbation and physiological constraints. The original model of Phillips et al. (1978) dealt with interactions shown within the bottom-up compartment. For simplicity feedback effects of macrophytes on piscivores and littoral invertebrates via provision of refugia are not shown. Note that in some lakes the piscivore, herbivore and molluscivore components will relate to both fish and waterbirds. 
Clear water, macrophyte dominated

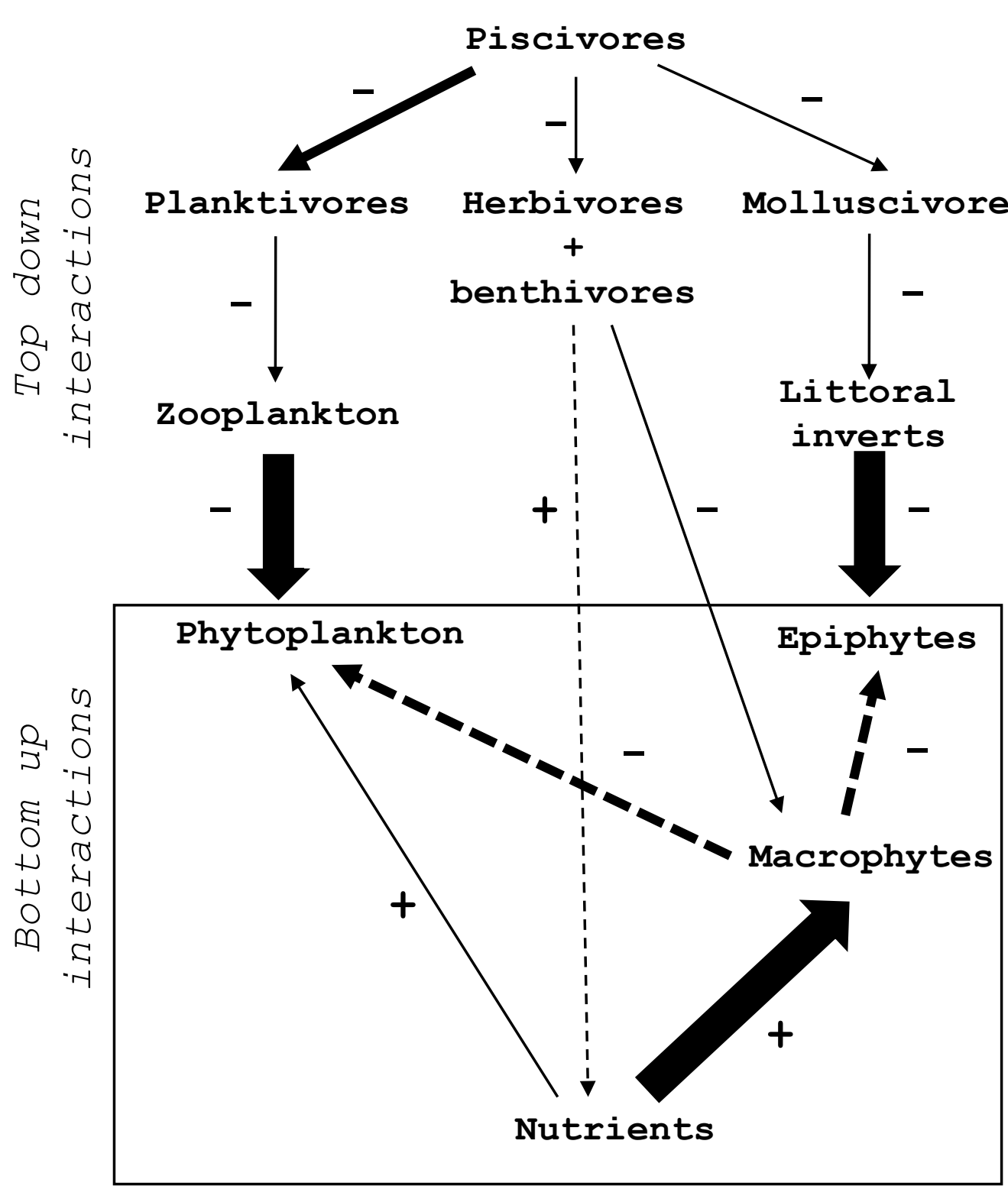

Key pressures

Habitat Ioss, DO

and ice-induced fish kills

Habitat loss, agrochemicals, other toxins, salinity

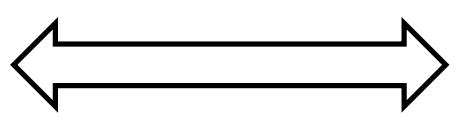

Non-native grazers, boating, weed-cutting, invasion, toxins, salinity, water level rise

Internal loading, increased external load
Turbid water, algae-dominated

Piscivores

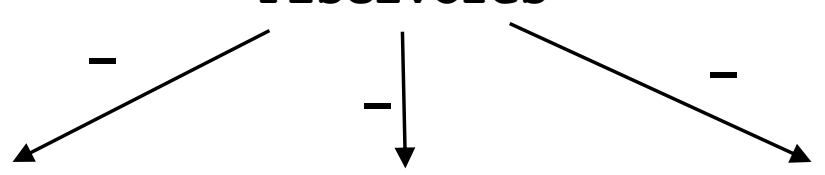

Planktivores Herbivores Molluscivores
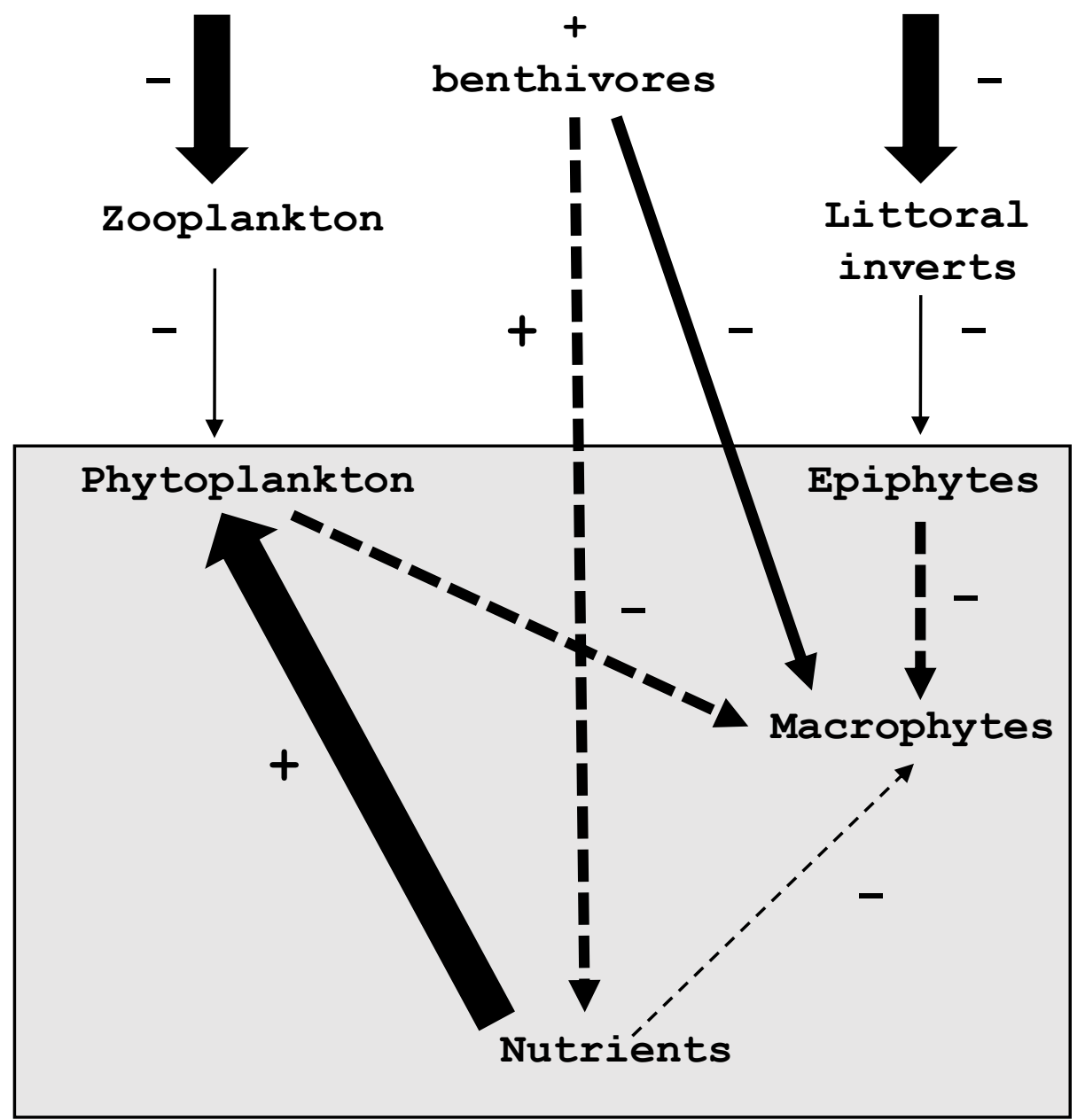